\title{
Trophic interactions of chaetognaths, larval fish, and zooplankton in the South Atlantic Bight
}

\author{
Christine T. Baier, Jennifer E. Purcell* \\ University of Maryland, Center for Environmental and Estuarine Studies, Horn Point Environmental Laboratory, PO Box 775. \\ Cambridge, Maryland 21613, USA
}

\begin{abstract}
Chaetognaths are highly abundant carnivores in marine environments, and feed both on fish larvae and on the same foods as fish larvae. We assessed predation by chaetognaths on winterspawned fish larvae and on the planktonic food of fish larvae in February 1992, December 1992, and February 1993 off the southeastern U.S. coast. Feeding rates of chaetognaths were calculated from gut content analysis and experimentally determined digestion rates, and combined with estumates of in situ densities of predators and prey. Chaetognath and larval fish distributions overlapped temporally and spatially on all dates. Densities of chaetognaths averaged 10 to $67 \mathrm{~m}^{-3}$, and fish larvae averaged 0.1 to $1.8 \mathrm{~m}^{-3}$ Only 1 fish larva was found in 6718 chaetognath guts examined. Effects of chaetognath predation on the abundant small prey consumed by the small fish larvae present in December 1992 and February 1993 were negligible $\left(0.3\right.$ to $0.7 \%$ consumed $\left.d^{-1}\right)$. In February 1992, however, chaetognaths consumed up to $44 \% \mathrm{~d}^{-1}$ of standing stocks of large copepods that also were prey of the large fish larvae present on that date. We conclude that chaetognaths were not important predators of fish larvae during this study, but may, at times, consume substantial amounts of the copepod populations, which are shared by fish larvae.
\end{abstract}

KEY WORDS: Chaetognaths $\cdot$ Competition - Fish larvae $\cdot$ Ichthyoplankton Predation $\cdot$ Sagitta $\cdot$ Zooplankton. Trophodynamics

\section{INTRODUCTION}

Chaetognaths are potentially important both as predators and competitors of larval fish. Chaetognaths are highly abundant in all oceans, often numbering second only to copepods, and are strictly carnivorous (Feigenbaum \& Maris 1984). Chaetognaths feed on fish larvae in the laboratory (Kuhlmann 1977), and reports of larvae in the guts of preserved chaetognaths are common in the literature (reviewed in Feigenbaum \& Maris 1984, Alvarino 1985, Feigenbaum 1991). Several researchers have speculated that chaetognaths cause significant mortality of fish larvae, based on the great abundances of chaetognaths and the presence of larvae in chaetognath guts (reviewed in Alvarino 1985). Previous information on the effects of chaetognath predation on larval fish is largely qualitative; the present study provides quantitative data.

- Addressee for correspondence.

E-mail:purcell@hpel.cees.edu
Copepods are the most important food of both chaetognaths and larval fish. Young chaetognaths begin feeding on small prey such as tintinnids and copepod nauplii, and then progress to copepods and other large prey (Feigenbaum \& Maris 1984). Similarly, first feeding larvae of many fish species feed on a variety of organisms, such as copepod nauplii, tintinnids, and mollusc larvae, and subsequently specialize on copepods (Hunter 1981) Several studies showed that chaetognath predation can significantly affect populations of copepods or larvaceans. For example, Sameoto (1973) estimated consumption by Sagitta elegans as $36 \%$ of annual secondary production in Bedford Basin. Nova Scotia (Canada), and concluded that chaetognaths were the most important predators of copepods in that location (other examples include Szyper 1978, Kimmerer 1984, Stuart \& Verheye 1991).

Predation and starvation are thought to be the main causes of larval fish mortality (e.g. Hunter 1981, Houde 1987). Predation may be the largest direct source of larval mortality (Bailey \& Houde 1989). Food limitation 
can kill larvae directly through starvation, but may have more important indirect effects by slowing larval growth rates and increasing predation-induced mortality (Houde 1987, Taggart \& Leggett 1987). Chaetognaths previously have not been evaluated as predators and competitors of fish larvae. Our study quantifies the trophic interaction of chaetognath predation on fish larvae and on the zooplankton prey-field of fish larvae off the southeastern coast of the United States during 3 observational periods.

\section{METHODS}

Distributions and abundances. Distributions of chaetognaths, fish larvae, and ambient zooplankton were estimated from depth-stratified samples collected in 5 min tows with a $1 \mathrm{~m}$ diameter multiple-openingclosing-net system (MOCNESS), from 5 locations in the South Atlantic Bight, during February 1992, December 1992, and February 1993 (Fig. 1, Table 1). Stn 120 (Dec 1992) was sampled approximately every $4 \mathrm{~h}$ for a $24 \mathrm{~h}$ period to assess diel changes in depth distributions and feeding. Bottom depths ranged from 24 to $34 \mathrm{~m}$, and the entire water column was sampled. The MOCNESS had $333 \mu \mathrm{m}$ mesh nets, and these samples were preserved in $95 \%$ ethanol. Fish larvae of the species Brevoortia tyrannus (Atlantic menhaden), Leiostomus xanthurus (spot), Paralichthys dentatus (summer flounder), Micropogonias undulatus (Atlantic croaker), the bothid flounders Bothus sp. and Syacium sp., and a cynoglossid (tonguefish) from the $333 \mu \mathrm{m}$ mesh nets were counted, identified, and measured to determine standard length. In Dec 1992 and Feb 1993, $0.25 \mathrm{~m}^{2}$ insets of $64 \mu \mathrm{m}$ mesh were put in each MOCNESS net to collect chaetognaths and zooplankton. These samples were preserved in a $5 \%$ formaldehyde solution.

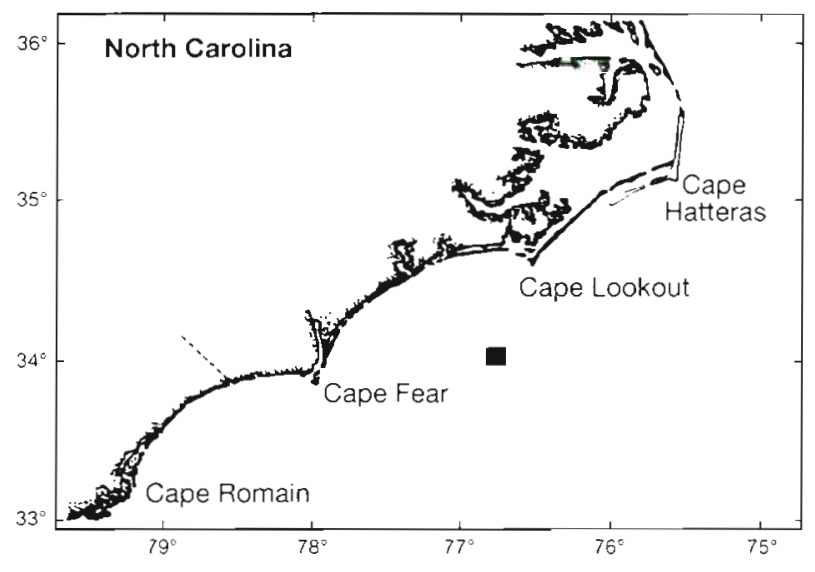

Fig. 1. Study area $(\mathbf{\square})$ off the southeastern U.S. coast

Subsamples were taken with a Folsom Plankton Splitter to obtain 100 to 300 chaetognaths from each sample. Chaetognaths were identified to species, counted, and measured to determine standard lengths (distance from the front of the head to the end of the tail, excluding fin) using a CUE-2 image analysis system. Very small chaetognaths and a few damaged specimens could not be identified and were included with 'other' chaetognaths.

After removing the chaetognaths, the remaining zooplankton sample was sieved through a $500 \mu \mathrm{m}$ mesh. Organisms from the $>500 \mu \mathrm{m}$ fraction were counted, identified to major taxa, and measured using the CUE-2 system. The $<500 \mu \mathrm{m}$ fraction was diluted and subsampled with the Folsom Plankton Splitter to obtain 100 to 300 organisms to count, identify, and measure

All statistical analyses were done using Statistical Analysis Systems (SAS) software (SAS Institute Inc., Cary, NC, USA). Analysis of Variance (ANOVA) was used to test for differences in densities and lengths of

Table 1. Station data for MOCNESS samples. Chaetognaths and zooplankton were collected from $333 \mu \mathrm{m}$ mesh nets in Feb 1992, and from $64 \mu \mathrm{m}$ mesh insets in Dec 1992 and Feb 1993. Fish larvae were collected from $333 \mu \mathrm{m}$ mesh nets on all dates. Densities averaged over all depths

\begin{tabular}{|c|c|c|c|c|c|c|c|c|c|}
\hline \multirow[t]{2}{*}{ Stn } & \multirow[t]{2}{*}{ Date } & \multirow{2}{*}{$\begin{array}{l}\text { Latitude } \\
\qquad(\mathrm{N})\end{array}$} & \multirow{2}{*}{$\begin{array}{l}\text { Longitude } \\
\text { (W) }\end{array}$} & \multirow{2}{*}{$\begin{array}{l}\text { Time } \\
\text { (h) }\end{array}$} & \multirow[t]{2}{*}{$\mathrm{I}\left({ }^{\circ} \mathrm{C}\right)$} & \multirow{2}{*}{$\begin{array}{c}\text { Bottom } \\
\text { depth }(m)\end{array}$} & \multirow{2}{*}{$\begin{array}{c}\text { Mesh } \\
\text { size (m) }\end{array}$} & \multicolumn{2}{|c|}{ Density $\left(\mathrm{no} \cdot \mathrm{m}^{-3}\right.$ ) } \\
\hline & & & & & & & & Chaet. & Fish larvae \\
\hline 107 & 1 Feb 92 & $34^{\circ} 04.10^{\prime}$ & $76^{\circ} 45.7^{\prime}$ & $11: 45$ & 15 & 31 & 333 & 43.6 & 0.9 \\
\hline 109 & 1 Feb 92 & $34^{\circ} 03.05^{\prime}$ & $76^{\circ} 45.5^{\prime}$ & $17: 00$ & 15 & 34 & 333 & 48.3 & 1.5 \\
\hline 110 & 1 Feb 92 & $34^{\circ} 02.97^{\prime}$ & $76^{\circ} 45.6^{\prime}$ & $19: 00$ & 15 & 32 & 333 & 66.9 & 1.8 \\
\hline 120 & $17 \mathrm{Dec} 92$ & $34^{\circ} 03.0^{\prime}$ & $76^{\circ} 45.0^{\prime}$ & $11: 35$ & 22 & 24 & 64 & 19.1 & 0.2 \\
\hline 120 & $17 \mathrm{Dec} 92$ & $34^{\circ} 03.0^{\prime}$ & $76^{\circ} 45.0^{\prime}$ & $17: 00$ & 22 & 34 & 64 & 40.8 & 0.3 \\
\hline 120 & $17 \operatorname{Dec} 92$ & $34^{\circ} 03.0^{\prime}$ & $76^{\circ} 45.0^{\prime}$ & $20: 45$ & 22 & 32 & 64 & 33.1 & 0.4 \\
\hline 120 & 18 Dec 92 & $34^{\circ} 03.0^{\prime}$ & $76^{\circ} 45.0^{\prime}$ & $00: 45$ & 22 & 30 & 64 & 10.0 & 0.1 \\
\hline 120 & 18 Dec 92 & $34^{\circ} 03.0^{\prime}$ & $76^{\circ} 450^{\prime}$ & $04: 45$ & 22 & 31 & 64 & 16.3 & 1.0 \\
\hline 120 & $18 \operatorname{Dec} 92$ & $34^{\circ} 03.0^{\prime}$ & $76^{\circ} 45.0^{\prime}$ & $08: 30$ & 21 & 32 & 64 & 37.6 & 0.3 \\
\hline 227 & 12 Feb 93 & $34^{\circ} 04.00^{\prime}$ & $76^{\circ} 47.0^{\prime}$ & $18: 30$ & 18 & 25 & 64 & 55.3 & 0.5 \\
\hline
\end{tabular}


fish larvae and chaetognaths among dates. Kolmogorov-Smirnov statistics were used to test for differences in depth and length frequency distributions (Kim \& Jennrich 1970).

Gut content analysis. Prey items in the guts of chaetognaths and fish larvae were identified and measured after excision from the guts using insect pins. The prosome length of copepods and the total length of other measurable zooplankters was measured using the CUE-2 system. Soft-bodied organisms such as larvaceans were not measured. Although prey diameter is thought to limit the size of prey consumed both by chaetognaths and larval fish (Pearre 1980, Hunter 1981), prey length was used in this study because it was difficult to measure diameters of partially digested prey. ANOVAs were used to test for differences in numbers of prey ingested by chaetognaths and fish larvae among stations, among depths within stations, and with time of day. Comparisons of least squares means were made using the Bonferroni approach (Tarone 1990).

Ambient zooplankton and prey in the guts of fish larvae and chaetognaths were categorized by major taxa. Prey that were not common to both chaetognaths and fish larvae were classified as 'other' prey. Samplesize-independent percent similarities (reviewed in Kohn \& Riggs 1982) were calculated as an index of diet overlap of chaetognaths and larval fish. Prey preferences were assessed using Pearre's (1982) electivity index. ANOVA was used to test for differences in prey size among dates.

Digestion rates. Digestion rate experiments were conducted at sea using chaetognaths collected in Dec 1992 and Feb 1993. Surface temperature was recorded at each station. Because chaetognaths are delicate and difficult to maintain and feed in the laboratory, we used a method that minimized handling. Chaetognaths were collected in series of very short $(<1 \mathrm{~min})$ vertical net tows (5 to $10 \mathrm{~m}$ ), using conical plankton nets. Samples were examined immediately over a light table, and chaetognaths with prey were isolated in 11 jars filled with $64 \mu \mathrm{m}$ filtered seawater, and maintained at the temperature of collection. Initial time of isolation, prey position in the gut, and prey type were recorded. Chaetognaths were observed in the jars at 15 min intervals until prey were egested or could no longer be seen in the gut. Then the chaetognaths were examined with a dissecting microscope for prey remnants, identified, and measured using an ocular micrometer. Regressions of these digestion times versus temperature for each species were used to estimate digestion times in the field from ambient temperatures. Estimated digestion times were multiplied by 2 , to allow for digestion that may have occurred before the observations began, as recommended by Feigenbaum (1991)
Feeding rates. The mean number of prey per chaetognath (NPC) was determined at each station for the predominant chaetognath species Sagitta enflata, $S$. helenae and S. hispida, and for 'other species'. Prey in the foregut and undigested prey were excluded from the analysis because they probably were consumed in the net (Baier \& Purcell 1997 this issue). NPCs were multiplied by 2 to account for prey loss due to gut evacuation during sampling and preservation (Baier \& Purcell 1997).

NPCs from the $24 \mathrm{~h}$ station at different times of day were compared using ANOVA. The $24 \mathrm{~h}$ station samples were assigned to day (08:30 to $17: 00 \mathrm{~h})$ or night (20:45 to 04:45 h). Sunrise was just before 07:00 h on all dates, while sunset was at approximately $17: 35 \mathrm{~h}$ on the February dates and at $16: 53 \mathrm{~h}$ in Dec 1992. The ratio of mean night NPC to day NPC (1.96) from the $24 \mathrm{~h}$ station was used to adjust daily feeding rates at stations where only day or night samples were collected.

The proportions of prey in chaetognath guts (all species combined) that represented potential prey of fish larvae (\% FP) were determined using 3 criteria. Prey types were excluded from the feeding effect calculations if they (1) were not found in fish larvae gut contents, (2) were outside of the size range consumed by larvae, or (3) could not be identified. The portion of the ambient zooplankton that represented potential prey of fish larvae on each date was determined by the same criteria. These percentages were applied to ambient zooplankton densities to obtain the densities of prey available to fish larvae $\left(\mathrm{FP} \mathrm{m}^{-3}\right)$.

Feeding rates were calculated for each station and chaetognath species using an equation modified from Bajkov (1935): Feeding rate $=(N P C / D) \times T$, where feeding rate is the number of prey ingested per chaetognath during each time period, NPC is the number of prey per chaetognath, $D$ is the digestion time in hours, and $T$ is the time period in hours. For each of the six $24 \mathrm{~h}$ samples, $T=4 \mathrm{~h}$; for all other samples, day $T=10 \mathrm{~h}$ and night $T=14 \mathrm{~h}$. Daily feeding rates (prey chaetognath ${ }^{-1} \mathrm{~d}^{-1}$ ) for each station and species were obtained by summing the feeding rates for those periods. The \%FP then was applied to obtain feeding rates of chaetognaths on potential prey of fish larvae.

Feeding eifects. The numbers of prey consumed $\mathrm{m}^{-3}$ $\mathrm{d}^{-1}$ by each chaetognath species were calculated by multiplying the daily feeding rate by the mean density for each species on each day. These values were then summed to yield the total number of prey consumed per day for all chaetognaths at each station $\left(\mathrm{P} \mathrm{m}^{-3} \mathrm{~d}^{-1}\right)$. The percentages of prey standing stocks consumed daily by chaetognaths $=\left(\mathrm{P} \mathrm{m}^{-3} \mathrm{~d}^{-1} / \mathrm{FP} \mathrm{m}^{-3}\right)$ $\times 100$. 


\section{RESULTS}

\section{Distributions and abundances}

Chaetognath and larval fish distributions overlapped on all dates and at all stations, and chaetognaths were always much more abundant (10 to $67 \mathrm{~m}^{-3}$ ) than fish larvae (0.1 to $1.8 \mathrm{~m}^{-3}$; Table 1$)$. Chaetognath densities were highest in Feb 1992 and 1993 (Fig. 2A). Sagitta enflata was the most abundant chaetognath species, followed by Sagitta helenae (Fig. 2A). Other species included Serratosagitta serratodentata, Sagitta minima, Pterosagitta draco, Krohnitta sp., Sagitta tenuis, Sagitta hexaptera, and Sagitta bipunctata. About $30 \%$ of chaetognaths in Dec 1992, compared with only $7 \%$ in Feb 1993, were unidentified juveniles (included with other species, Fig 2A) that were too small to be sampled quantitatively by the $333 \mu \mathrm{m}$ mesh net used in Feb 1992. Fish larvae of the target species were much less abundant than other species and densities were greatest in Feb 1992 (Table 1, Fig. 2B).
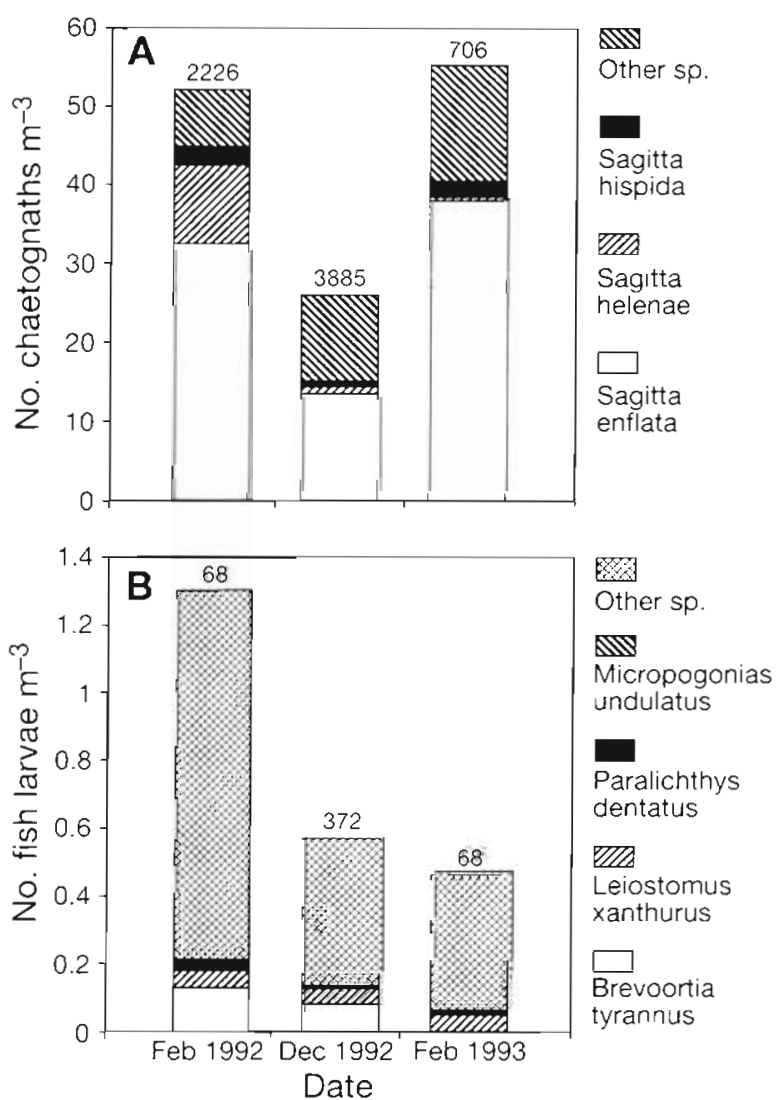

Fig. 2. Densities and species compositions of (A) chaetognaths and (B) larval fish on 3 sampling dates. Numbers above bars represent no. of chaetognaths examined $(A)$, and no. of fish larvae measured and used for gut content analysis (B). Chaetognaths were examined from $333 \mu \mathrm{m}$ mesh samples in Feb 1992 and from $64 \mu \mathrm{m}$ mesh samples on the other dates. All fish larvae in $333 \mathrm{~m}$ samples were identified
At the 24 h station (Dec 1992), chaetognaths and fish larvae were distributed throughout the water column at all times. The depth distributions of chaetognaths and larval fish appeared to be roughly similar at each sampling time, except at 04:45 $\mathrm{h}_{\text {; }}$ however, the distributions were significantly different at all times except 11:30 $\mathrm{h}$ and 17:00 h (Kolmogorov-Smirnov statistic, $\mathrm{p}<$ 0.05 , Fig. 3). Fish larvae were distributed more towards the surface at $04: 45 \mathrm{~h}$, which was significantly different from the distributions at other times of day (Kolmogorov-Smirnov statistic, $p<0.05$ ), whereas chaetognaths were distributed more towards the bottom then than at other sampling times.

\section{Diel patterns and diet}

Diel patterns. Chaetognaths fed most actively at night while fish fed mainly during daylight hours (Fig. 4). The mean number of prey per chaetognath
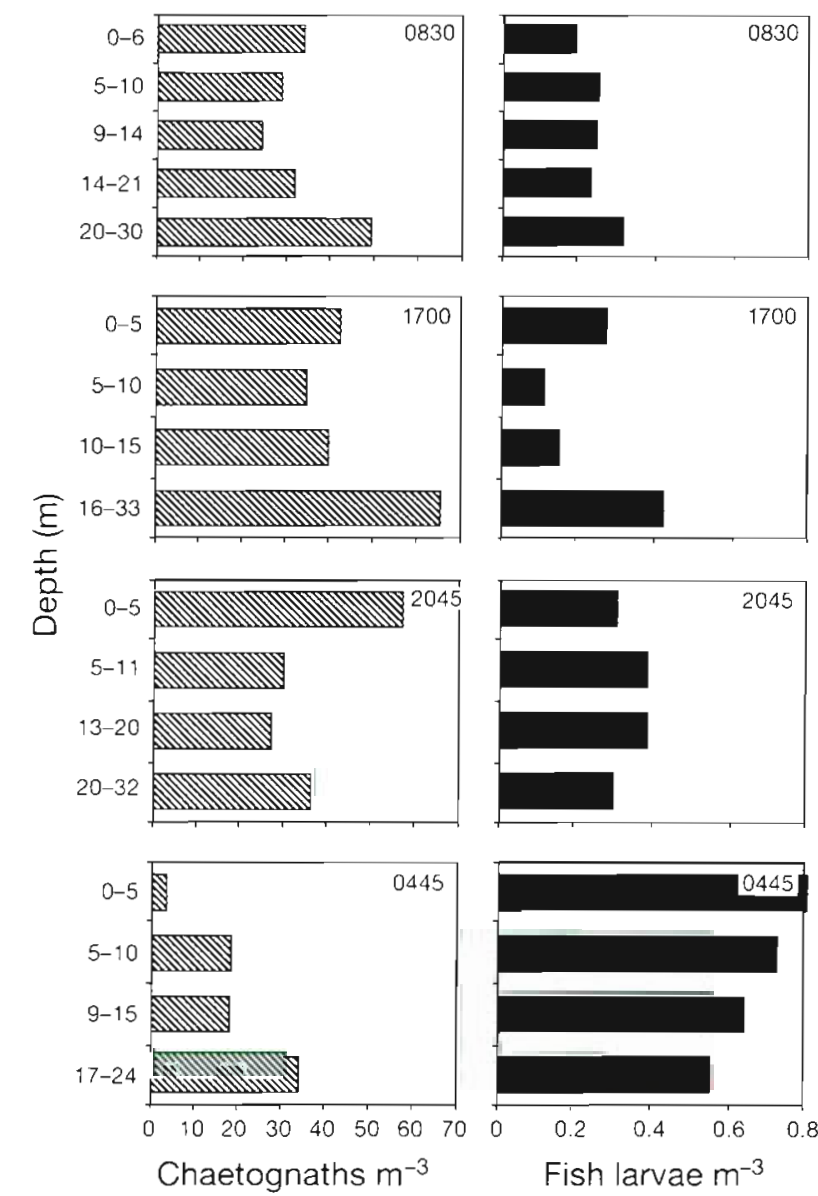

Fig. 3. Depth distribution in relation to time of day for chaetognaths (hatched bars) and fish larvae (solid bars) at the $24 \mathrm{~h}$ station in Dec 1992. Distributions at 11:30 h (not shown) were similar to those at $08: 30$ and $17: 00 \mathrm{~h}$. Distributions at 00:45 h are not shown because the net dragged the bottom 


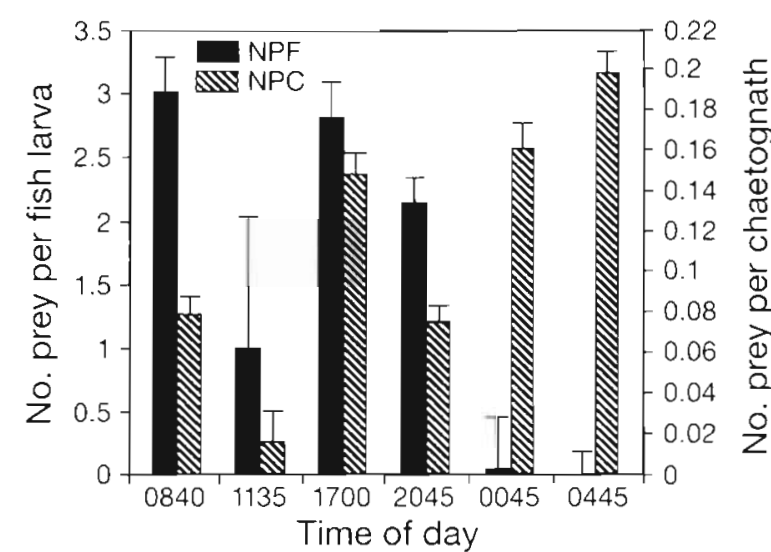

Fig. 4. Comparison of feeding by chaetognaths (NPC, before adjusting for prey loss) and fish larvae (NPF) in relation to time of day in Dec 1992. Variance shown as \pm 1 standard error. Data averaged over entire water column except at 04:45 h, when the 25 to $31 \mathrm{~m}$ sample is missing. No of chaetognaths and larvae examined shown in Fig. 2

(NPC, not adjusted for prey loss) was significantly greater at night $(0.089 \pm 0.006)$ than during the day $(0.045 \pm 0.008)$. Heavy feeding by chaetognaths at 04:45 h coincided with markedly different vertical distributions of chaetognaths and larval fish (Fig. 3). The number of prey per fish larva (NPF) was significantly higher during the day $(2.87 \pm 0.33)$ than at night $(1.02$ $\pm 0.17)(p<0.001$; Fig 4$)$. Active feeding of both fish larvae and chaetognaths occurred at dusk (17:00 h).

Prey types. Only 1 of the 6817 chaetognaths examined from all samples contained a fish larva. Copepods were the most important prey items of chaetognaths on all dates, accounting for $42 \%$ of the diet in Dec $1992,44 \%$ in Feb 1993 , and nearly $90 \%$ in $333 \mu \mathrm{m}$ mesh samples from Feb 1992. The chaetognaths collected in $64 \mu \mathrm{m}$ mesh nets were smaller than those collected in $333 \mu \mathrm{m}$ mesh nets, and contained a greater diversity of prey, including some microzooplankton. Copepod nauplii (20\%) and tintinnids (18\%) were important prey items of chaetognaths in Dec 1992. In Feb 1993, copepod nauplii and larvaceans each accounted for $20 \%$ of total prey.

Although it represented only a small proportion of the fish larvae in the samples (Fig. 2), Leiostomus xanthurus contained most of the prey found in Feb 1992 (100\%), Dec 1992 (97\%) and Feb 1993 (81\%). Copepods were the most important prey of fish larvae in Feb 1992 (100\%) and 1993 (68\%; Table 2). In Dec 1992 tintinnids (51\%) outnumbered copepods (22\%) as prey items, and such small prey items as invertebrate eggs were found only on this date.

Chaetognaths were more selective than fish larvae for prey type (Table 2). In both Dec 1992 and Feb 1993, chaetognaths selected for copepods and larvaceans, and in Feb 1993 tintinnids were selected for as well. By contrast, fish larvae consumed most prey types in proportion to their ambient densities (selection was not significantly different from zero) (Table 2). Electivities for Feb 1992 were not calculated since small ambient prey were not sampled quantitatively.

Prey sizes. The prey sizes consumed by chaetognaths were similar to those consumed by larval fish (Fig. 5A, B, C). Both consumed prey in approximate proportion to the sizes available in Dec 1992. In Feb 1993, however, relatively few small $(<0.25 \mathrm{~mm})$ prey were eaten by chaetognaths or fish larvae, while a disproportionately large percentage of prey in the 0.25 to $0.50 \mathrm{~mm}$ size class was consumed.

Mean lengths of chaetognath prey in Dec $92(0.33 \pm$ $0.32 \mathrm{~mm}$ ) were significantly different $(p<0.001)$ from Feb 1992 (0.95 $\pm 0.94 \mathrm{~mm}$ ) and Feb 1993 (0.52 \pm $0.42 \mathrm{~mm}$; Fig. 5A, B, C). The differences in prey sizes reflected significant differences in chaetognath lengths

Table 2. Composition of prey items in the diet of larval fish from $333 \mu \mathrm{m}$ mesh nets, and chaetognaths, and ambient densities (averaged over depths and times) of prey retained by $64 \mu \mathrm{m}$ mesh net. Indices of prey selection (C) were calculated according to Pearre (1982). 'Other' prey include rare prey such as amphipods, mysids, and chaetognaths. Asterisks denote statistical significance, $p p<0.05, \cdots p<0.005$

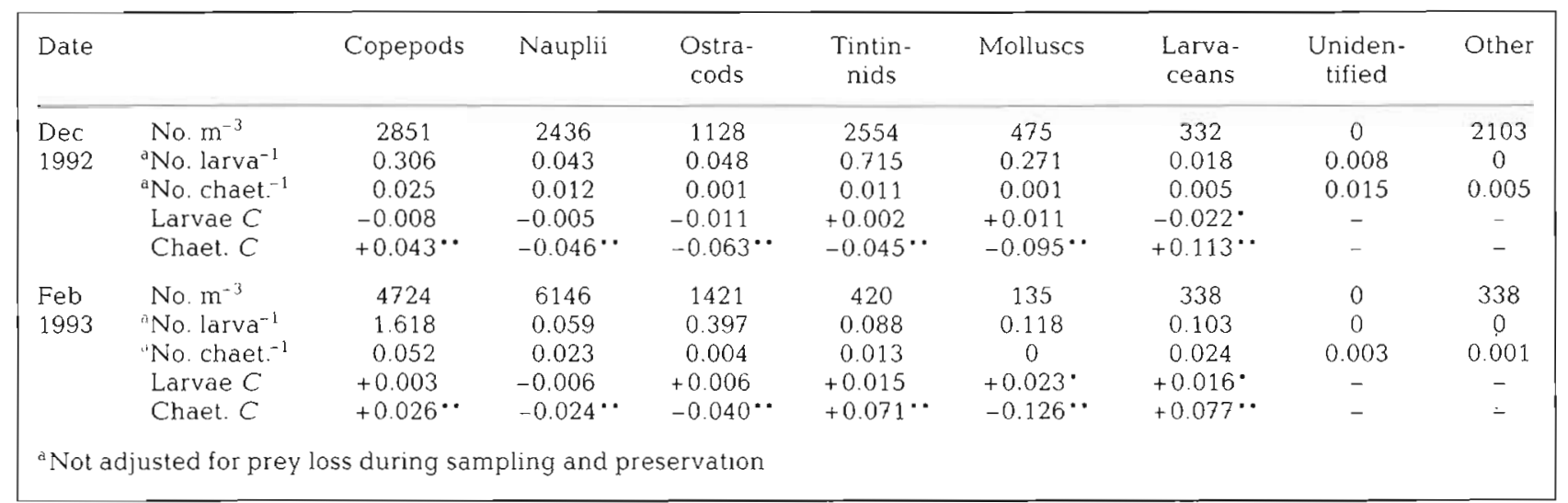



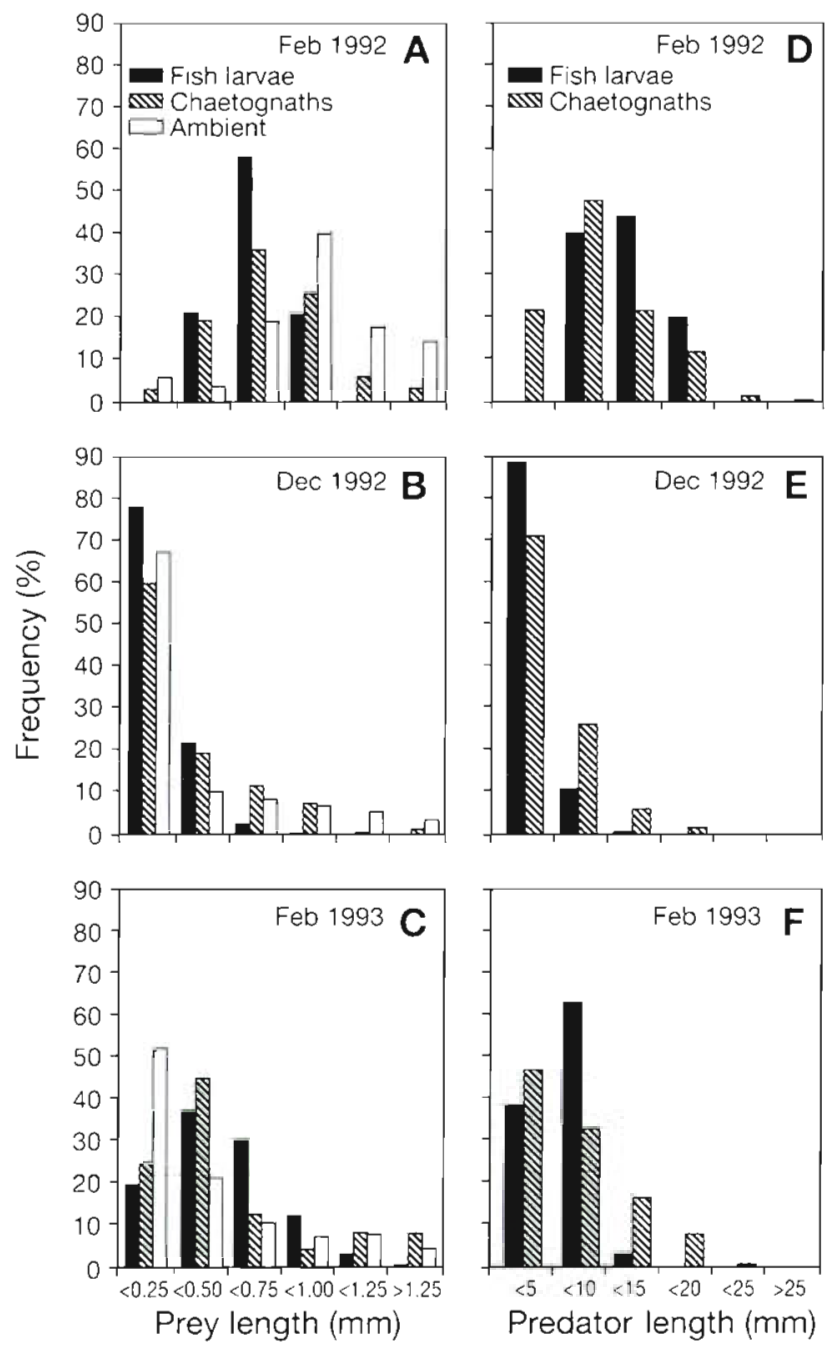

Fig. 5. ( $A, B, C)$ Length frequencies of prey in gut contents of chaetognaths and fish larvae, and of ambient zooplankton, and $(D, E, F)$ length frequencies of chaetognaths and fish larvae on 3 sampling dates. All fish larva data are from $333 \mu \mathrm{m}$ mesh net samples. Chaetognaths and zooplankton are from $333 \mu \mathrm{m}$ mesh nets in Feb 1992, and from $64 \mu \mathrm{m}$ mesh nets in Dec 1992 and Feb 1993. Numbers of ambient zooplankton examined shown in Table 3 among dates: Dec 1992 (4.48 $\pm 0.06 \mathrm{~mm})$, Feb 1992 $(8.82 \pm 0.085 \mathrm{~mm})$, and Feb 1993 (6.90 $0.15 \mathrm{~mm})(\mathrm{p}<$ 0.001 , Fig. 5D, E, F). Differences in net mesh size cannot explain these observed size differences; Dec 1992 and Feb 1993 samples were from $64 \mu \mathrm{m}$ mesh, and Feb 1992 samples were from $333 \mu \mathrm{m}$ mesh.

Mean prey sizes of larval fish also differed significantly among sampling dates: Feb 1992 (0.62 \pm $0.13 \mathrm{~mm})$, Dec $1992(0.18 \pm 0.13 \mathrm{~mm})$, and Feb 1993 $(0.49 \pm 0.26 \mathrm{~mm})(\mathrm{p}<0.001$; Fig. 5A, B, C). As with chaetognaths, these prey sizes reflected significantly different fish larvae lengths among dates $(p<0.001$, Fig. 5D, E, F). All fish larva data are from $333 \mu \mathrm{m}$ mesh samples; hence the smaller fish sizes in Dec 1992 and Feb 1993 do not reflect sampling with fine-mesh insets.

The lengths of the fish larvae sampled were greater than the lengths of the largest prey consumed by chaetognaths on all dates. The maximum prey size consumed by chaetognaths was $6.61 \mathrm{~mm}$ in Feb 1992, at which time fish larvae averaged $11.85 \pm 0.24 \mathrm{~mm}$ in length. In Dec 1992, when fish larvae averaged $3.74 \pm$ $0.12 \mathrm{~mm}$, the maximum size of prey in chaetognath guts was only $1.64 \mathrm{~mm}$. In Feb 1993, larval fish averaged $5.86 \pm 0.24 \mathrm{~mm}$ and the maximum size of prey consumed by chaetognaths was only $1.61 \mathrm{~mm}$.

Considering both types and sizes of prey, chaetognath and larval fish diets overlapped to the greatest extent (88\%) in Dec 1992 (Table 3). The percentage of ambient zooplankton that represented potential prey of larval fish also was highest ( $82 \%$ ) on that date. The percentage of potential fish prey in chaetognath gut contents $(-60 \%)$, and in the ambient zooplankton (35 to $40 \%$ ), was similar in Feb of both years.

\section{Feeding rates and effects}

Digestion rates. The temperatures in our study were lower than in other studies of Sagitta enflata and $S$. hispida, and digestion times were longer (Table 4).

Table 3. Types and size ranges of prey in diets of larval fish on 3 dates, used to determine the proportion of potential prey of larval fish (FP) in chaetognath diets and in ambient zooplankton. N: number of prey examined from fish guts. Number of prey examined from chaetognath guts and from ambient zooplankton shown in parentheses. Number of fish larvae and chaetognaths examined shown in Fig. 2. Overlaps of fish larva and chaetognath diets by prey type only are given in brackets

\begin{tabular}{|c|c|c|c|c|c|c|}
\hline Date & $N$ & Prey types & $\begin{array}{l}\text { Prey } \\
\text { Min. }\end{array}$ & $\begin{array}{l}(\mathrm{mm}) \\
\operatorname{Max}\end{array}$ & $\begin{array}{l}\% \text { FP in } \\
\text { chaet. guts }\end{array}$ & $\begin{array}{l}\% \mathrm{FP} \\
\text { ambient }\end{array}$ \\
\hline Feb 1992 & 60 & Copepods [91\%] & 0.36 & 0.89 & $\begin{array}{c}63.3 \\
(268)\end{array}$ & $\begin{array}{c}40.7 \\
(5785)\end{array}$ \\
\hline Dec 1992 & 533 & $\begin{array}{l}\text { Tintinnids, copepods, molluscs, } \\
\text { ostracods, nauplii, larvaceans, eggs }[48 \%]\end{array}$ & 0.02 & 0.91 & $\begin{array}{r}88.4 \\
(505)\end{array}$ & $\begin{array}{c}82.2 \\
(14617)\end{array}$ \\
\hline Feb 1993 & 168 & $\begin{array}{l}\text { Copepods, ostracods, larvaceans, } \\
\text { tintinnids, molluscs, naupli1 }[58 \%]\end{array}$ & 0.04 & 1.54 & $\begin{array}{c}60.0 \\
(146)\end{array}$ & $\begin{array}{c}34.9 \\
(2141)\end{array}$ \\
\hline
\end{tabular}


Table 4. Digestion time $(D)$, temperature $(T)$, number of observations $(N)$, and methods from the literature and from this study for Sagitta enflata, S helenae, and S. hispida. Lab: fed in lab; in situ: prey consumed in situ, observed digestion times multiplied by 2 Regr: proportion of chaetognaths with prey regressed on the time to preservation

\begin{tabular}{|c|c|c|c|c|c|c|}
\hline Species & $D(\min )$ & $T\left({ }^{\circ} \mathrm{C}\right)$ & $N$ & Prey & Method & Source \\
\hline S. enflata & $\begin{array}{l}40 \\
60 \\
190.2 \pm 48.6 \\
166.7 \pm 33.1 \\
253.5 \pm 94.0 \\
433.2 \pm 152.8\end{array}$ & $\begin{array}{l}- \\
24-26 \\
23 \\
21-25 \\
16-20 \\
12-15\end{array}$ & $\begin{array}{r}1 \\
- \\
13 \\
15 \\
8 \\
5\end{array}$ & $\begin{array}{l}\text { Chaet. } \\
\text { Natural } \\
\text { Copepods } \\
\text { Natural } \\
\text { Natural } \\
\text { Natural }\end{array}$ & $\begin{array}{l}\text { Lab } \\
\text { Regr. } \\
\text { Lab } \\
\text { in situ } \\
\text { in situ } \\
\text { in situ }\end{array}$ & $\begin{array}{l}\text { Grey }(1930) \\
\text { Szyper }(1978) \\
\text { Feigenbaum }(1979) \\
\text { This study } \\
\text { This study } \\
\text { This study }\end{array}$ \\
\hline S. helenae & $\begin{array}{l}176.7 \pm 42.7 \\
275.5 \pm 82.8 \\
352.1 \pm 120.4\end{array}$ & $\begin{array}{l}21-24 \\
16-20 \\
12-15\end{array}$ & $\begin{array}{l}21 \\
32 \\
18\end{array}$ & $\begin{array}{l}\text { Natural } \\
\text { Natural } \\
\text { Natural }\end{array}$ & $\begin{array}{l}\text { in situ } \\
\text { in situ } \\
\text { in situ }\end{array}$ & $\begin{array}{l}\text { This study } \\
\text { This study } \\
\text { This study }\end{array}$ \\
\hline S. hispida & $\begin{array}{l}60-120 \\
180-240 \\
272.5 \pm 52.1\end{array}$ & $\begin{array}{c}21 \\
- \\
13\end{array}$ & $\begin{array}{c}250 \\
- \\
11\end{array}$ & $\begin{array}{l}\text { Natural } \\
\text { Copepods } \\
\text { Natural }\end{array}$ & $\begin{array}{l}\text { Lab } \\
\text { Lab } \\
\text { in situ }\end{array}$ & $\begin{array}{l}\text { Reeve (1980) } \\
\text { Cosper \& Reeve (1975) } \\
\text { This study }\end{array}$ \\
\hline
\end{tabular}

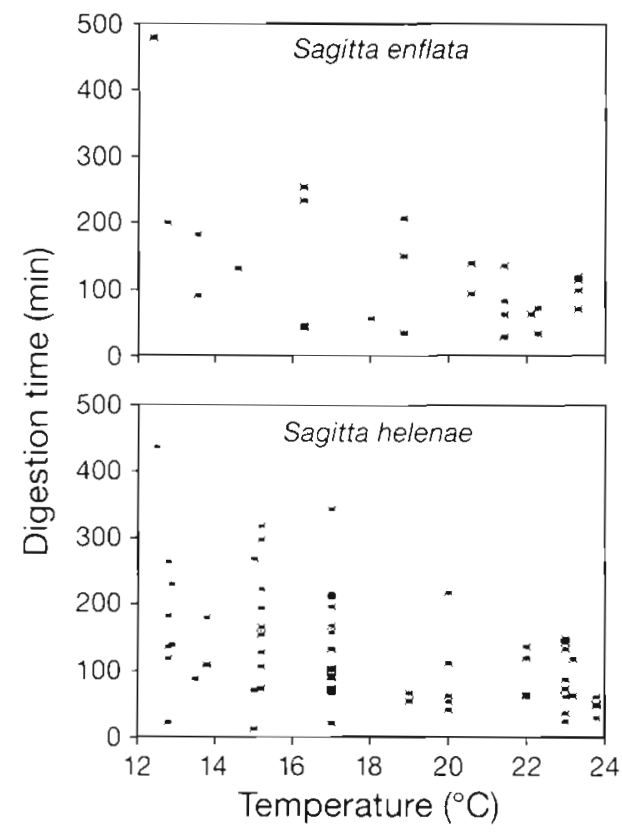

Fig. 6. Sagitta enflata and S. helenae. Relationship of digestion time (in min, before multiplying by 2) to temperature. Regression equation for $S$ enflata: $D=2\{371.42-12.34 T\}$, $\mathrm{R}^{2}=0.302(\mathrm{p}<0.003) ;$ for $S$. helenae: $D=2(282.70-11.27 T)$, $\mathrm{R}^{2}=0.202(\mathrm{p}<0.0001)$
Increased temperature significantly reduced digestion times of $S$. enflata and $S$. helenae (Fig. 6). Linear regressions of digestion times with temperature gave better fits than logarithmic regressions and so were used to estimate digestion times for the feeding rate calculations.

Feeding rates. The numbers of prey per chaetognath (NPC) differed significantly among stations ( $p<0.001)$ but not among depths within stations, so feeding rates for each station were averaged over all depths (Table 5). Sagitta enflata had low individual feeding rates compared with $S$. helenae and $S$. hispida, but because of its high densities, $S$. enflata consumed the most zooplankton at all but one station (Table 5).

Feeding effects. Chaetognaths removed considerable portions (12.3 to $44.4 \% \mathrm{~d}^{-1}$ ) of the standing stock of larval fish prey in Feb 1992, but not on other dates $\left(0.3\right.$ to $0.7 \% \mathrm{~d}^{-1}$. Table 6$)$. The most important factor determining the effect of chaetognath predation was the density of available prey. The relatively large larval fish present in Feb 1992 fed exclusively on copepods between 0.36 and $0.89 \mathrm{~mm}$ in length. These copepods were present in the environment in much lower densities than the microzooplankton, small copepods, and other prey that predominated in larval diets in Dec

Table 5. Chaetognath feeding rates as number of prey consumed chaetognath-1 $\mathrm{d}^{-1}\left(\mathrm{P} \mathrm{c}^{-1} \mathrm{~d}^{-1}\right)$; chaetognath densities $\left(c \cdot \mathrm{m}^{-3}\right)$ averaged over all depths and times; and number of prey consumed $\mathrm{m}^{-3} \mathrm{~d}^{-1}$ by chaetognaths $\left(\mathrm{P} \mathrm{m}^{-3} \mathrm{~d}^{-1}\right)$

\begin{tabular}{|c|c|c|c|c|c|c|c|c|c|c|c|c|c|}
\hline Date & Stn & $\begin{array}{r}S a \\
\mathrm{P} \mathrm{c}^{-1} \mathrm{~d}^{-1}\end{array}$ & $\begin{array}{l}\text { gitta en } \\
\text { c. } \mathrm{m}^{-3}\end{array}$ & $\begin{array}{l}\text { flata } \\
\mathrm{P} \mathrm{m}^{-3} \mathrm{~d}^{-1}\end{array}$ & $\mathrm{P} \mathrm{c}^{-1} \mathrm{~d}^{-1}$ & $\begin{array}{l}\text { itta he } \\
\text { c. } \mathrm{m}^{-3}\end{array}$ & $\begin{array}{l}\text { enae } \\
\mathrm{P} \mathrm{m}^{-3} \mathrm{~d}^{-1}\end{array}$ & $\mathrm{Pc}^{-1} \begin{array}{r}\operatorname{Sagl} \\
\mathrm{d}^{-1}\end{array}$ & $\begin{array}{l}\text { itta hist } \\
\text { c. } \mathrm{m}^{-3}\end{array}$ & $\begin{array}{l}\text { pida } \\
\mathrm{P} \mathrm{m}^{-3} \mathrm{~d}^{-1}\end{array}$ & $\mathrm{PC}_{\mathrm{C}^{-1}} \begin{array}{l}\mathrm{Oth} \\
\mathrm{d}^{-1}\end{array}$ & $\begin{array}{l}\text { er spec } \\
\text { c. } \mathrm{m}^{-3}\end{array}$ & $\begin{array}{l}\mathrm{P} \mathrm{m}^{-3} \mathrm{~d}^{-1}\end{array}$ \\
\hline Feb 92 & $\begin{array}{l}107 \\
109 \\
110\end{array}$ & $\begin{array}{l}0.99 \\
0.41 \\
1.01\end{array}$ & $\begin{array}{l}30.0 \\
28.0 \\
38.8\end{array}$ & $\begin{array}{l}29.7 \\
11.5 \\
39.1\end{array}$ & $\begin{array}{l}2.74 \\
0.91 \\
2.08\end{array}$ & $\begin{array}{r}3.8 \\
8.9 \\
19.8\end{array}$ & $\begin{array}{r}10.3 \\
8.1 \\
41.2\end{array}$ & $\begin{array}{l}0.83 \\
2.13 \\
0.87\end{array}$ & $\begin{array}{l}3.0 \\
2.8 \\
1.1\end{array}$ & $\begin{array}{l}2.4 \\
6.0 \\
1.0\end{array}$ & $\begin{array}{l}2.45 \\
0.62 \\
0.70\end{array}$ & $\begin{array}{l}6.9 \\
8.6 \\
7.2\end{array}$ & $\begin{array}{r}17.0 \\
5.3 \\
4.9\end{array}$ \\
\hline Dec 92 & 120 & 1.14 & 13.3 & 15.1 & 0.98 & 1.0 & 1.0 & 4.23 & 0.8 & 3.5 & 0.31 & 10.9 & 3.4 \\
\hline Feb 93 & 227 & 0.86 & 37.7 & 32.5 & 4.21 & 0.6 & 2.4 & 2.53 & 2.1 & 5.2 & 0.24 & 14.9 & 3.5 \\
\hline
\end{tabular}


Table 6 . Effects of chaetognath predation on available prey of larval fish. $\mathrm{P} \mathrm{m}^{-3} \mathrm{~d}^{-1}$ : Number of prey consumed $\mathrm{m}^{-3} \mathrm{~d}^{-1}$ by all species of chaetognaths; FP $\mathrm{m}^{-3} \mathrm{~d}^{-1}$ : number of potential fish prey (determined from percentages in Table 3 ) consumed by all species of chaetognaths; FP $\mathrm{m}^{-3}$. density of ambient FP. Feb 1992 estimates based on samples collected in $333 \mu \mathrm{m}$ mesh nets; all others collected in $64 \mu \mathrm{m}$ mesh nets

\begin{tabular}{|lcrrrrr|}
\hline Date & Stn & $T\left({ }^{\circ} \mathrm{C}\right)$ & $\begin{array}{c}P \\
\mathrm{~m}^{-3} \mathrm{~d}^{-1}\end{array}$ & $\begin{array}{c}\mathrm{FP} \\
\mathrm{m}^{-3} \mathrm{~d}^{-1}\end{array}$ & $\begin{array}{c}\mathrm{FP} \\
\mathrm{m}^{-3}\end{array}$ & $\begin{array}{c}\% \text { available FP } \\
\text { consumed } \mathrm{d}^{-1}\end{array}$ \\
\hline Feb 92 & 107 & 15 & 76.9 & 48.5 & 109.4 & 44.4 \\
& 109 & 15 & 40.0 & 25.3 & 206.2 & 12.3 \\
& 110 & 15 & 111.3 & 70.5 & 303.5 & 23.2 \\
Dec 92 & 120 & 22 & 29.6 & 26.2 & 8376.0 & 0.3 \\
Feb 93 & 227 & 18 & 56.3 & 33.8 & 5808.0 & 0.7 \\
\hline
\end{tabular}

1992 and Feb 1993. Therefore, although chaetognaths consumed only slightly fewer prey per day in Dec 1992 and Feb 1993 than in Feb 1992, their estimated impacts were negligible on the highly abundant microzooplankton prey populations present on those dates.

\section{DISCUSSION}

\section{Predation on fish larvae}

Only 1 fish larva was found in the 6817 chaetognaths examined, compared with hundreds of other prey organisms. We believe that chaetognaths were not important predators of fish larvae during this study because various factors may have reduced the likelihood of such predation. Specifically, the impact of predators depends on the temporal and spatial overlap of predator and prey, the individual vulnerability of fish larvae to each predator taxon, and the availability of alternative prey (Bailey \& Houde 1989).

Temporal and spatial overlap. Although chaetognath and larval fish distributions overlapped on all dates and at all stations, the peak spawning period of Brevoortia tyrannus, Leiostomus xanthuras, and Micropogonias undulatus may have coincided with seasonally low abundances of adult chaetognaths. These fish species spawn most intensively during winter over the mid- and outer continental shelf of North Carolina (Govoni \& Pietrafesa 1994), and peak spawning activity of B. tyrannus in 1992 was in December (L. Crowder pers. comm.). Chaetognath abundances in our study were about half as high in Dec as in Feb samples, and others have found that adult populations of many chaetognath species are low during the winter (e.g. Owre 1960, Cheney 1985, Terezaki 1993).

Fish larvae may reduce the risk of predation by avoiding the depth strata occupied by their predators (Frank \& Leggett 1985). Menhaden Brevoortia tyrannus make a shallow migration to the surface to fill their swim bladders, allowing the larvae to rest at the surface at night (Hoss et al. 1989). In our study, many larval fish, particularly $B$. tyrannus, were near the surface during the night, when chaetognaths were more abundant in deeper water. By being less active at night, fish larvae also may reduce detection by chaetognaths, which locate prey by mechanoreception and feed more at night (reviewed in Feigenbaum 1991).

Vulnerability of fish larvae. Even when populations of predators and fish larvae overlap, subtle differences in the predator-prey size ratio can affect larval mortality (Purcell 1985, Bailey \& Houde 1989). During our study, many chaetognaths were too small to consume fish larvae when larvae were small enough to be vulnerable. Early winter appeared to be a breeding period for chaetognaths as well as for larval fish. We found that juveniles measuring $<5 \mathrm{~mm}$ were a major component $(30 \%)$ of the chaetognaths sampled in Dcc 1992 , during the peak spawning period of Brevoortia tyrannus, compared with only $7 \%$ in Feb 1993. Both laboratory and field studies have shown that only fish larvae within a limited size range are vulnerable to chaetognath predation. Kuhlmann (1977) found that fish larvae of several species were susceptible to chaetognath predation only after the larvae began to swim actively (1 d) and before they became too large or strong to be consumed (10 d). Alvarez-Cadena (1993) found that small herring Clupea harengus larvae (5 to $9 \mathrm{~mm}$ ) accounted for up to $7 \%$ of the prey of Sagitta elegans, but found no predation on larvae larger than $16 \mathrm{~mm}$.

Availability of alternative prey. The most important reason for low predation rates by chaetognaths on fish larvae during this study probably was the scarcity of fish larvae relative to other available prey. Fish larvae densities averaged only about $1 \mathrm{~m}^{-3}$ overall. Other prey types were $10^{2}$ to $10^{3}$ times more numerous. Also, chaetognaths may have preferred other prey types to fish larvae (Kuhlman 1977).

\section{Predation on food sources of larval fish}

Predation by chaetognaths could limit the food resources of fish larvae, possibly leading to starvation. Houde (1994) noted that the small size, high metabolic demand, and high required ingestion rates of marine fish larvae make starvation probable if food resources are limited. Several studies indicate that some larvae are starving, or that growth is slowed by food limitation (e.g. O'Connell 1980, Theilacker 1986, Buckley \& Lough 1987, Robinson \& Ware 1988, Hovenkamp 1990, Canino et. al. 1991, Hovenkamp \& Witte 1991)

Food limitation may indirectly contribute to fish larvae mortality via several mechanisms. Low food levels 
can slow larval growth rates, thus increasing the amount of time that fish larvae are vulnerable to predation (Houde 1987). Unfed larvae were less able to escape from predators than fed larvae (Bailey \& Yen 1982, Purcell et al. 1987). Encounters with predators may increase if larvae swim more in search of scarce prey (Munk \& Kiørboe 1985). The cumulative indirect effects of food limitation may be even more important in the long term than the direct effects of predation (Taggart \& Leggett 1987).

In our study, we did not establish that fish larvae were food limited. We evaluated the importance of chaetognaths as potential competitors of fish larvae by examining the effects of chaetognath predation on the specific types and sizes of prey consumed by fish larvae. Predation effects were determined from the degree of dietary overlap of chaetognaths and fish larvae, the consumption capacity of chaetognaths, and the abundances of available prey.

Dietary overlap. The diets of chaetognaths and larval fish overlapped considerably on all dates. The prey types and sizes changed among dates, apparently reflecting the trophic ontogenies (changes in diet with growth) of both fish larvae and chaetognaths. Our results were consistent with studies showing that chaetognaths (Sullivan 1980, Kimmerer 1984, Stuart \& Verheye 1991, Gibbons 1992) and fish larvae (Economou 1991) consume larger prey over a greater size-range as they grow.

Feeding rates. Feeding rate estimates for chaetognaths were low in this study, as compared with studies in the laboratory and studies using $\leq 2$ min tows (Szyper 1978, Kimmerer 1984; Table 7). Prey losses during our long tow durations may have been greater than estimated (Baier \& Purcell 1997). Temperatures were generally lower during this study than during other studies of Sagitta enflata and $S$. hispida, and digestion times were accordingly longer (Table 4), which contributed to low feeding rates. Low feeding rates also could be due to the relatively low prey densities, especially as compared with those used in laboratory studies (reviewed in Feigenbaum \& Maris 1984).

Differences in feeding rates among dates may be explained in part by differences in chaetognath species and sizes. For example, because of its high individual feeding rates, Sagitta helenae consumed as much prey as $S$. enflata in Feb 92, even though densities of $S$. enflata were twice as great (Table 5). Feeding rates have been shown to be positively related to chaetognath length (e.g. Feigenbaum 1979, Kimmerer 1984) and to be lower in immature chaetognaths (Øresland 1987). In Dec 1992, when chaetognaths were small and $30 \%$ were juveniles, NPCs were lower than on the Feb dates, despite the high abundance of microzooplankton prey in Dec (Table 5).

Feeding effects. Abundances of the different prey consumed by larval fish on each date was the most important factor determining the potential effects of chaetognaths on prey populations. Chaetognaths would only have affected the food resources of fish larvae in Feb 1992, when fish larvae were larger than on other dates, and specialized on large copepods. Although chaetognath and larval fish diets overlapped on all dates, the small, diverse prey that larvae consumed in Dec 1992 and Feb 1993 were too abundant to be affected by chaetognath predation. To our knowledge, no other studies have evaluated the potential for competition between chaetognaths and fish larvae; however, some have examined predation effects on popu-

Table 7. Feeding rates of chaetognaths, as number of prey chaetognath ${ }^{-1} \mathrm{~d}^{-1}\left(\mathrm{P} \mathrm{c}^{-1} \mathrm{~d}^{-1}\right)$. Modified from Feigenbaum (1991)

\begin{tabular}{|llccl|}
\hline Species & Location & $T\left({ }^{\circ} \mathrm{C}\right)$ & $\mathrm{P} \mathrm{C}^{-1} \mathrm{~d}^{-1}$ & Source \\
\hline Sagitta enflata & Laboratory & 21 & 10.0 & Reeve (1980) \\
& Kaneohe Bay, Hawaii & - & 10.1 & Kimmerer (1984) \\
& Kaneohe Bay, Hawail & $24-26$ & 7.4 & Szyper (1978) \\
& Florida Current & - & 2.2 & Feigenbaum (1979) \\
& Virginia Shelf & 25 & 1.3 & Bushing \& Feigenbaum (1984) \\
& South Atlantic Bight & 22 & 1.1 & This study \\
& South Atlantic Bight & 18 & 0.9 & This study \\
& South Atlantic Bight & 15 & 0.8 & This study \\
Sagitta helenae & South Atlantic Bight & 22 & 1.0 & This study \\
& South Atlantic Bight & 18 & 4.2 & This study \\
& South Atlantic Bight & 15 & 1.9 & This study \\
Sagitta hispida & Laboratory & 24 & $5-60$ & Reeve (1964) \\
& Laboratory & 26 & 23.7 & Reeve (1970) \\
& Laboratory & 21 & 14.1 & Reeve (1970) \\
& Laboratory & 16 & 10.8 & This study \\
& South Atlantic Bight & 22 & 4.2 & This study \\
& South Atlantic Bight & 18 & 2.5 & This study \\
\hline
\end{tabular}


lations of copepods and other zooplankton. Szyper (1978) found that small copepods in Kaneohe Bay, Hawail, were too numerous $\left(3 \times 10^{4} \mathrm{~m}^{-3}\right)$ to be much affected by chaetognath predation, but larvacean populations were significantly reduced. Kimmerer (1984) found that chaetognaths removed 4 to $12 \%$ of copepod standing stock daily, but speculated that effects on specific size groups could be much greater, since the chaetognaths were size-selective. Stuart \& Verheye (1991) found that Sagitta friderici removed 1.0 to $5.3 \%$ of copepod standing stock off South Africa.

Chaetognath predation has been shown to have the greatest effects on copepod populations during periods of low copepod production. Sameoto (1973) estimated that Sagitta elegans consumed only $1 \%$ of yearly copepod production, but up to $50 \%$ of winter production. $\varnothing$ resland (1990) found that daily predation by Eukrohnia hamata on copepods in Antarctic waters was 0.03 to $0.06 \%$ of the standing stock, and estimated that this predation could reduce copepod populations by about $12 \%$ in winter, when most copepods do not reproduce. Unfortunately, we are not aware of any estimates of copepod production for the South Atlantic Bight. Copepod abundances, reproduction, and growth rates are low in winter on the inner shelf (Pomeroy et al. 1993), but zooplankton rate processes are high throughout the year on the outer shelf (Verity et al. 1993). The sampling stations in our study were located over the mid-shelf, and may be influenced by both inner- and outer-shelf processes.

Chaetognaths were not important predators of fish larvae during this study, and had a negligible effect on the abundant microzooplankton prey of the small fish larvae present in Dec 1992 and Feb 1993; however, predation by chaetognaths removed as much as $44 \%$ of standing stocks of the large copepods that the relatively large fish larvae preyed on in Feb 1992. Because of the great abundance of chaetognaths, their predation on copepod populations may, at times, be a major factor affecting prey available to larval fish.

Acknowledgements. We thank Don Hoss, Jeff Govoni, Larry Settles and Dave Peters for logistical support on the cruises and for density data on larval fish. Dave Nemazie helped with sampling at sea. Linda Coston-Clements provided helpful background information. Dan Jacobs directed statistical analyses. Ed Houde, Larry Sanford, and John Petersen provided many helpful comments on the manuscript. We are grateful to George Grant, who verified the chaetognath species identifications, and to Ed Houde for identifying some of the fish larvae. This research was part of the South Atlantic Bight Recruitment Experiment, which is sponsored by the NOAA Coastal Ocean Program's Coastal Fisheries Ecosystems project, and was funded through grant no. NA.26RG0413 from the Maryland Sea Grant Program. Additional funding was provided by the Horn Point Environmental Laboratory. UMCEES Contribution No. 2782.

\section{LITERATURE CITED}

Alvarez-Cadena JN (1993) Feeding of the chaetognath Sagitia elegans Verrill. Estuar Coast Shelf Sci 36:195-206 Alvarino A (1985) Predation in the plankton realm; mainly with reference to fish larvae. Inv Mar CICIMAR 2:1-122

Baier CT, Purcell JE (1996) Effects of sampling and preservation on apparent feeding by chaetognaths. Mar Ecol Prog Ser $146: 37-42$

Bailey KM, Houde ED (1989) Predation on eggs and larvae of marine fishes and the recruitment problem. Adv Mar Biol 25: $1-83$

Bailey KM, Yen J (1982) Predation by a carnivorous manine copepod, Euchaeta elongata Esterly, on eggs and larvae of the Pacific hake, Merluccius productus. J Plankton Res $5: 71-81$

Bajkov AD (1935) How to estimate the daily food consumption of fish under natural conditions. Trans Am Fish Soc 65: 288-289

Buckley LJ, Lough RG (1987) Recent growth, biochemical composition, and prey field of larval haddock (Melanogrammus aeglefinus) and Atlantic cod (Gadus morhua) on Georges Bank. Can J Fish Aquat Sci 44:14-25

Bushing M. Feigenbaum D (1984) Feeding by an expatriate population of Sagitta enflata. Bull Mar Sci 34:240-243

Canino MF, Bailey KM. Incze LS (1991) Temporal and geographic differences in feeding and nutritional condition in walleye pollock larvae Theragra chalcogramma in Shelikof Strait, Gulf of Alaska. Mar Ecol Prog Ser 79 $27-35$

Cheney J (1985) Spatial and temporal abundance patterns of oceanic chaetognaths in the western North Atlantic-I. Hydrographic and seasonal abundance patterns. Deep Sea Res 9:1041-1059

Cosper TC, Reeve MR (1975) Digestive efficiency of the chaetognath Sagitta hispida Conant. J Exp Mar Biol Ecol $17: 33-38$

Economou AN (1991) Food and feeding ecology of five gadoid larvae in the northern. North Sea. J Cons Int Explor Mer 47:339-351

Feigenbaum D (1979) Daily ration and specific daily ration of the chaetognath Sagitta enflata. Mar Biol 54:75-82

Feigenbaum D (1991) Food and feeding behavior. In: Bone Q, Kapp H, Pierrot-Bults AC (eds) The biology of chaetognaths. Oxford University Press, New York, p 45-54

Feigenbaum DL, Maris RC (1984) Feeding in the Chaetognatha. Oceanogr Mar Biol Ann Rev 22:343-392

Frank KT, Leggett WC (1985) Reciprocal oscillations in densities of larval fish and potential predators: a reflection of present or past predation? Can J Fish Aquat Sci 42: $1841-1849$

Gibbons MJ (1992) Diel feeding and vertical migration of Sagitta serratodentata Krohn tasmanica Thomson (Chaetognatha) in the southern Benguela. J Plankton Res 14: $249-259$

Govoni JJ, Pietrafesa LJ (1994) Eulerian views of layered water currents, vertical distribution of some larval fishes, and inferred advective transport over the continental shelf off North Carolina, USA in winter. Fish Oceanogr 3: $120-132$

Grey BB (1930) Chaetognatha from the Society Islands. Proc R Soc Queensl 42:62-67

Hoss DE, Checkley DM Jr, Settle LR (1989) Diurnal buoyancy changes in larval Atlantic menhaden (Brevoortia tyrannus). Rapp P-V Reun Cons Int Explor Mer 191:105-111

Houde ED (1987) Fish early life dynamics and recruitment variability. Am Fish Soc Symp 2:17-29 
Houde ED (1994) Differences between marine and freshwater fish larvae: implications for recruitment. ICES J Mar Sci 51:91-97

Hovenkamp F (1990) Growth differences in larval plaice Pleuronectes platessa in the Southern Bight of the North Sea as indicated by otolith increments and RNA/DNA. ratios. Mar Ecol Prog Ser 58:205-215

Hovenkamp F, Witte JI (1991) Growth, otolith growth, and RNA/DNA ratios of larval plaice Pleuronectes platessa in the North Sea 1987 to 1989. Mar Ecol Prog Ser 70:105-116

Hunter JR (1981) Feeding ecology and predation of manne fish larvae. In: Lasker RR (ed) Marine fish larvae: morphology, ecology and relation to fisheries. University of Washington Press, Seattle, p 35-77

Kim PJ, Jennrich Rl (1970) Tables of the exact sampling distribution of the two sample Kolmogorov-Smirnov criterion $\mathrm{D}_{\mathrm{m}, \mathrm{n}} \mathrm{m} \leq \mathrm{n}$. In: Harter, Owen (eds) Selected tables in mathematical statistics. Markham Publishing Co, Chicago

Kimmerer WJ (1984) Selective predation and its impact on prey of Sagitta enflata (Chaetognatha). Mar Ecol Prog Ser 15:55-62

Kohn AJ, Riggs AC (1982) Sample size dependence in measures of proportional similarity. Mar Ecol Prog Ser 9: $147-151$

Kuhlmann D (1977) Laboratory studies on the feeding behaviour of the chaetognaths Sagitta setosa J. Muller and $S$. elegans Verril with special reference to fish eggs and larvae as food organisms. Ber Dtsch Wiss Komm Meeresforsch 25:163-171

Munk P, Kiorboe T (1985) Feeding behavior and swimming activity of larval herring (Clupea harengus) in relation to density of copepod nauplir. Mar Ecol Prog Ser 24:15-21

O'Connell CP (1980) Percentage of starving northern anchovy, Engraulis mordax, larvae in the sea as estimated by histological methods. Fish Bull US 78:475-489

$\varnothing$ resland V (1987) Feeding of the chaetognaths Sagitta elegans and $S$. setosa at different seasons in Gullmarsfjorden, Sweden. Mar Ecol Prog Ser 39:69-79

Øresland V (1990) Feeding and predation impact of the chaetognath Eukrohnia hamata in Gerlache Strait. Antarctic Peninsula. Mar Ecol Prog Ser 63:201-209

Owre HB (1960) Plankton of the Florida Current. Part VI. The Chaetognatha. Bull Mar Sci Gulf Caribb 10:255-322

Pearre S Jr (1980) Feeding by Chaetognatha: the relation of prey size to predator size in several species. Mar Ecol Prog Ser 3:125-134

Pearre S Jr (1982) Estimating prey preference by predators: uses of various indices, and a proposal for another based on $\chi^{2}$ Can J Fish Aquat Sci 39:914-923

Pomeroy LR, Blanton JO, Paffenhöfer GA, Von Damm KL, Verity PG, Windom $H L$, Lees TN (1993) Inner shelf pro-

This article was presented by $K$. Sherman (Senior Editorial Advisor), Narragansett, Rhode Island, USA cesses. In: Menzel DW (ed) Ocean processes: US Southeast continental shelf. US Dept Energy

Purcell JE (1985) Predation on fish eggs and larvae by pelagic cnidarians and ctenophores. Bull Mar Sci 37:739-755

Purcell JE, Siferd TD, Marliave JB (1987) Vulnerability of larval herring (Clupea harengus pallasi) to capture by the jellyfish Aequorea victoria. Mar Biol 94:157-162

Reeve MR (1964) Feeding of zooplankton, with special reference to some experiments with Sagitta. Nature 201: $211-213$

Reeve MR (1970) The biology of Chaetognatha l. Quantitative aspects of growth and egg production in Sagitta hispida In: Steele $\mathfrak{J H}$ (ed) Marine food chains. Oliver \& Boyd. Edinburgh, p 168-169

Reeve MR (1980) Comparative experimental studies on the feeding of chaetognaths and ctenophores. J Plankton Res $2: 381-393$

Robinson SMC, Ware DM (1988) Ontogenetic development of growth rates in larval Pacific herring, Clupea harengus pallasi, measured with RNA-DNA ratios in the Strait of Georgia, British Columbia. Can J Fish Aquat Sci 45: $1422-1429$

Sameoto DD (1973) Annual life cycle and production of the chaetognath Sagitta elegans in Bedford Basin, Nova Scotia. J Fish Res Bd Can 30:333-344

Stuart V. Verheye HM (1991) Diel migration and feeding patterns of the chaetognath, Sagitta friderici, of the west coast of South Africa. J Mar Res 49:493-51.5

Sullivan BK (1980) In situ feeding behavior of Sagitta elegans and Eukrohna hamata (Chaetognatha) in relation to the vertical distribution and abundance of prey at Ocean Station ' $P$ ' Lumnol Oceanogr 25:317-326

Szyper JP (1978) Feeding rate of the chaetognath Sagitta enflata in nature. Estuar ( oast Mar Sci 7:567-575

Taggart CT', Leggett WC (1987) Short-term mortality in postemergent larval capelin Mallotus villosus. Importance of food and predator density, and density-dependence. Mar Ecol Prog Ser 41:219-229

Tarone RE (1990) A modified Bonferroni method for discrete data. Biometrics 46:515-522

Terazaki M (1993) Seasonal variation and life history of the pelagic chaetognath, Sagitta elegans Verrill, in Toyama Bay, southern Japan Sea. J Plankton Res 15:703-714

Theilacker GH (1986) Starvation-induced mortality of young sea-caught jack mackerel, Trachurus symmetricus, determined by histological and morphological methods. Fish Bull US 84:1-17

Verity PG, Lee TN, Yoder JA, Paffenhöfer GA, Blanton JO, Alexander CR (1993) Outer shelf processes. In: Menzel DW (ed) Ocean processes: US Southeast continental shelf. US Dept Energy

Manuscript first recelved: November 5, 1995

Revised version accepted: November 11, 1996 